\title{
Energizing Local Values For Tourism Services Improvement
}

\author{
Budi Purnomo \\ Sahid Tourism Institute of Surakarta \\ Jl. Adi Sucipto 154 Solo, Central Java, Indonesia 57144 \\ budipurnomo989@yahoo.co.id
}

\begin{abstract}
People in most cultures would probably agree that politeness is needed during their interaction. However there may be differing opinions as to when they should be polite. In tourism industry, tourism service providers' act as hosts and tourists act as guests. Typically hosts will try to act politely and use appropriate politeness norms when serving guests to ensure their satisfaction. The research findings show that the tourism service providers in Central Java use various unggah-ungguh 'politeness norms' when serving English speaking tourists and Indonesian speaking tourists. Besides that, there are some violations made by the tourism service providers in using unggah-ungguh 'politeness norms'. The research findings also show that there are similar and different perspectives on unggah-ungguh 'politeness norms' between English speaking tourists with Western culture backgrounds and Indonesian speaking tourists with Indonesian culture backgrounds towards the politeness norms used by the tourism service providers in Central Java. The findings imply the needs of energizing unggah-ungguh 'politeness norms' which is discovered from well known noble Javanese values used by the tourism service providers for tourism service improvement.
\end{abstract}

Keywords: Local Values, Politeness Norms, Tourism Service Improvement 


\begin{abstract}
Abstrak
Masyarakat di sebagian besar budaya mungkin akan setuju bahwa kesopanan diperlukan selama mereka berinteraksi. Namun demikian mungkin ada perbedaan pendapat mengenai kapan mereka harus bersikap sopan. Dalam industri pariwisata, penyedia jasa pariwisata bertindak sebagai tuan rumah dan wisatawan bertindak sebagai tamu. Biasanya tuan rumah (host) akan mencoba untuk bertindak sopan dan menggunakan norma-norma kesopanan yang tepat ketika melayani tamu untuk memastikan kepuasan mereka. Hasil penelitian juga menunjukkan bahwa penyedia jasa pariwisata di Jawa Tengah menggunakan berbagai bentuk "unggah-ungguh" 'kesopanan norma' ketika melayani wisatawan berbahasa Inggris dan wisatawan berbahasa Indonesia. Di samping itu, ada beberapa pelanggaran bahasa yang dilakukan oleh penyedia jasa pariwisata dalam menggunakan 'norma kesopanan' atau bentuk "unggahungguh". Hasil penelitian juga menunjukkan bahwa ada perspektif yang sama dan berbeda pada bentuk "unggah-ungguh" atau 'norma kesopanan ' antara wisatawan berbahasa Inggris dengan latar belakang budaya Barat dan wisatawan berbahasa Indonesia dengan latar belakang budaya Indonesia terhadap norma-norma kesopanan yang digunakan penyedia jasa pariwisata di Jawa Tengah. Temuan ini menyiratkan kebutuhan untuk mendayagunakan unggah-ungguh 'kesopanan norma' yang diambil dari dari nilai-nilai luhur orang Jawa yang masyhur digunakan oleh penyedia jasa pariwisata untuk memperbaiki kualitas pelayanan kepariwisataan.
\end{abstract}

Kata Kunci: Nilai-Nilai Lokal, Norma Kesopanan, Peningkatan Kualitas Pelayanan Pariwisata

\title{
Introduction
}

As one of the main tourism centres in Indonesia, Central Java is a destination with many places of interest for tourists. Places of interaction between tourists and tourism service providers in this area include the airports, bus stations, train stations, tourist information centres, travel agencies, hotels, and restaurants, places of tourist interest, souvenir shops and excursions. The language tourism service providers use during interaction in these many and varied locations - both verbal and non- 
verbal - plays an important role in satisfying tourist's needs.

A basic goal of the tourism industry anywhere in the world is to provide an enjoyable and positive memorable experience for tourists. This can be especially accomplished by tourism service providers who are not only skilful in providing their services, but who also know how to communicate well and use appropriate nuances of politeness.

In the tourism industry, tourists act as guests and tourism service providers act as hosts. As the hosts, tourism service providers serve guests as well as possible in order to ensure the guests' satisfaction. Levels of satisfaction can be determined by the politeness of the hosts' behaviour towards their guests, including the politeness of their verbal language. This research project focuses on the use of local wisdoms by the tourism service providers in Central Java, Indonesia to improve services to their tourists.

Tourism-service language is a type of language commonly used by tourism service providers to serve their tourists. According to Astika (2004:109) and Samiati et. al. (2008: v), the tourism-service language appears in the kinds of interaction between tourists and tourism service providers which can be further classified into (1) receiving reservations, (2) meeting tourists at the airport/railway station, (3) providing information upon arrival on the way to the hotel, (4) helping tourists with their registration, (5) handling telephone enquiries, (6) giving directions, (7) giving information about art performances and entertainment, (8) beginning a tour and describing the itinerary, (9) describing points of interest on the tour route, (10) serving meals at restaurants, (11) describing processes used in making art objects (batik, leather puppets, gamelan instruments, etc.), (12) bargaining for souvenir prices and (13) 
describing tourist sites.

Typically tourism service providers will try to act politely and use appropriate manners when communicating with tourists to ensure harmonious communication. In an interaction tourists and tourism service providers will co-operate with each other in order that their speech can flow well, and so that each speaker can understand what they want through each other's utterances. Considered in the light of the host/guest roles of service provider and tourist, communicative interaction would certainly seek to avoid acts that could irritate the hearer's feeling and the interaction would use certain strategies to reduce any unhappy feelings on the part of the hearer. In Indonesia, particularly in Central Java, unique politeness conventions can be identified in comparison with those typically applied in Western countries (European countries, USA and Australia). Poedjosoedarmo (2009) suggests unggah-ungguh 'politeness norms' as a typical form of Javanese values. As an intangible cultural heritage, unggah-ungguh had been written in Serat Wedharaga by R. Ng. Ranggawarsita - a well-known Javanese wise man in the nineteenth century - and the revitalisation and redefinition by Poedjosoedarmo (2009) lead up to norms that are easy to be learned by young generation.

The operational questions this research addresses are: how is the unggah-ungguh 'politeness norms' used by tourism service providers when serving tourists in Central Java? Secondly, are there similar and different perspectives on unggah-ungguh 'politeness norms' used by tourism service providers in Central Java when serving English speaking tourists whose backgrounds are Western cultures and Indonesian speaking tourists whose backgrounds are Indonesian cultures? 


\section{'Unggah-ungguh'(politeness norms) as local values}

One of the major approaches to politeness in Indonesia is Poedjosoedarmo's (2009) theory of unggah-ungguh 'politeness norms' (an extension of "Language etiquette in Indonesia, 1978). As in "The Javanese speech levels" that he wrote in 1968, his theory is supposed to be an ideal principle of language propriety, and not a description of actual fact as typically occurring nowadays. Some young Javanese who claim themselves to be modern or liberal may wish to observe a different principle of propriety, and disregard the advice of their parents and teachers.

Different from the situation in Western countries where the typical person is monolingual, most Javanese people are now bilingual, speaking Javanese and Indonesian. For some of them who work as tourism service providers in Central Java, they are multilingual, speaking Javanese, Indonesian, English and other foreign languages.

Besides, the Javanese language makes use of distinct speech levels, which means distinct speech codes, which therefore reflect a slightly different practice of politeness in Indonesia, especially in Central Java from those adhered to by the Western people. Poedjosoedarmo (2009:1) explains the Javanese term unggah-ungguh (politeness norms) as a typical politeness of Javanese people. The norms are in the forms of idioms or set phrases which most parents and teachers actually use when they educate their children/students. Some are in the forms of positive advice (using positive idioms) and others are in the forms of prohibition (using negative imperative aja 'don't' do this or that).

Poedjosoedarmo states that politeness norms are implemented in four kinds of attitudes which should be practiced by a speaker in 
communicating. It starts by how an individual (first participant, P1) should act or behave as a participant in the social network in general. Secondly, what one should do when he/she is engaging in a interaction with an interlocutor (P1 to P2). Third, to suit the speech event, what topic and aim of speech should be expressed and with what means of communication one should express it. Fourthly, how should the speech act be constructed, and in what mood should one express the speech. In addition, how should a person handle his/her physical gestures to accompany the speech acts.

The followings are the idioms and set of phrases adapted from Poedjosoedarmo's politeness norms (2009:2-7) that are suggested to be implemented by tourism service providers when serving tourists in Central Java, Indonesia:

In a host-guest communication, a host has to be sumanak (from the stem sanak 'family' plus infix -um-). One should try to treat his guest as sanak 'relative, family', so the communication can be very smooth. With this friendly acceptance of friendship, an acquaintance will feel at ease, and a good social relation will prevail.

On the other hand, when the host becomes the addressee, he/she should then be tanggap 'responsive' or tanggap ing sasmita 'responsive toward the finest sign' of the guest. When the guest wants to converse with him/her, the host should be nggatekake, which means he/she should care to pay attention to what the guest says, and ready to respond to him/her. The host should not only pay attention to the actual words the addresser has uttered, but to the gestures accompanying the speech as well. In addition, it is advisable to be sumeh, showing a cheerful face while engaging in a conversation. It is not good to be mrengut 'frowning 
or showing a sour face'.

Sabar 'patient' and sareh 'calm and easy' are attributes that are good to be observed in many occasions, especially when talking to guests. During a conversation, one must not gampang nesu 'get easily angry', gampang muntab 'get hot temper' and mutungan 'easily feeling broken, frustrated'. Parents often say aja ladak 'don't be quarrelsome', aja nyenyengit 'don't be hateful', aja galak 'don't be vicious', and aja kumaki 'don't be cocky, don't be a brag'.

When a host is talking to a guest, there are three idioms usually used: tepa slira, andhap asor and ngajeni. When the guest is someone of the lower status than his/her own, he/she should act tepa slira. This may mean 'position oneself at the place of the addressee'. To be brief, it can be translated as 'be considerate'. In other words, it is 'showing a feeling of sympathy or solidarity'. If the guest is not able to speak Indonesian well, join him/her in using Javanese. If the guest does not speak the respectful or high krama well, join him/her in using the madya (middle, moderate) level. If the guest does not know how to express the idioms of gratefulness and complementation in a nice way, just accept it. The host has to be momot, which means 'accommodating'.

When the guest is from the same higher social status than the host, the host should be andhap asor. This literally means 'low and humble'. The host should give the guest a high respect. The host may speak to the guest in a respectful code, using high polite krama (the polite level) when the host wants to show distant relation, or ngoko (ordinary level) with honorific vocabulary if the host wants to be intimate with the guest. If the guest speaks to the host in English, he/she can respond accordingly, using polite English. 
In terms of the content, the host should give appreciation and complementation to the guest when the situation is right. The host must ngajeni, meaning 'giving high respect, proper appreciation'. The host must give the guest complementation whenever the opportunity is right.

In connection with the above principles, the host must never act umuk 'conceited'. S/he must not seneng nggunggung diri 'brag or indulge in showing oneself off'. S/he must not be degsura 'selfcentered'. The host must not allow oneself to afflict shameful feeling toward the guest. S/he must not gawe wirang, meaning literally 'cause shame'. The host is prohibited to gawe serik 'cause ill feeling' to the guest.

When the host wants to initiate a conversation, s/he must see to it that his/her topic and objective agree with the principle of empan papan. This literally means 'agree with the setting and occasion'. It must suit the speech event and agree with the mood of the guest. When the host is asking something that is not considered proper in relation to the speech event, s/he may be said to be benyunyak-benyunyuk 'improper and unwelcome speech initiator'. It would be better if the host just continue talking about the topic that has just been talked about. This way it can be relevant, because the topic connects with the current discussion. People will say that the host is nyambung 'relates to or connects with' the interlocutor.

Another thing to care about is the means by which the topic of the discourse is expressed. At present there is a choice to convey messages, i.e. whether to use a telephone, cellular phone, letter, electronic mail or saying it orally. There are things that must be handled orally in the presence of the interlocutor, there are those that have to be delivered 
officially with full care, there are those that can be conveyed via the telephone and via the cellular phone, but there are those that are considered proper to be expressed only through letters or electronic mail.

When a tourism service provider wants to speak, there is a principle s/he should observe, viz. пији prana. It literally means 'pleasing the heart' of the addressee. It includes the way s/he enunciates the words, the sequence of the sentences in the discourse, and the content of the message. The speech must be delivered with good enunciation, pleasing intonation and nice tempo. Everything must resep 'pleasing' or ngresepake 'causing pleasant feeling'. The speech must be delivered in a sareh 'reasy, calm' and cetha 'clear, distinct' way.

The discourse should be cekak aos 'brief but comprehensive'. Cekak means brief and aos means full of content. The tourism service provider must not speak in a nggladrah way 'utter long, irrelevant and unnecessary things'. The speech should be runtut 'ordered in a good sentence', and not tumpang suh 'in disorder with lots of overlapping'. The content should be pleasing, not nylekit, sengol, sengak, nglarani ati, or marakke nesu (aja nylekit, aja sengol, aja sengak, aja thok léh, isine sing bener, sing prasaja, ora goroh, aja njlomprongake) and the gestures should be suba sita 'in appropriate speech act' and trapsila 'in proper manner'.

From the above explanation, it can be inferred that there are six politeness norms as stated by Poedjosoedarmo (2009): Norm 1: Sumanak 'Friendly', Norm 2: Sabar lan sareh 'Patient and with ease, calm', Norm 3: Tepa slira 'Showing a feeling of sympathy or solidarity', Norm 4: Andhap asor 'Giving a high respect, appropriate appreciation', Norm 5: Empan papan 'Matches with the setting and occasion' and Norm 6: Nuju 
prana 'Pleasing, satisfying'.

\section{Cross-cultural perspectives on 'unggah-ungguh'(politeness norms)}

Almost all research views politeness as a universal feature of civilized societies, regardless of their background culture, or their language. Politeness is thus seen as an important social value, inherent to successful communication, although its realization may vary across the different speech communities. Politeness offers a good method of emotional control of the individual (House and Kasper, 1981:158), and is typically a means of preserving and maintaining good social relationships between the speakers of one or more cultures. Polite behavior generally protects the individual, as well as their addressee.

The verbal realization of politeness poses even greater problems when the interlocutors belong to different cultures and try to communicate, transferring their pragmatic knowledge of polite behavior into the foreign language. Lack of practice and or a learners' uncertainty in rendering correctly the grammatical structures of foreign language in the first place often lead to misunderstandings, or the so-called 'sociopragmatic failures' (Thomas, 1983), that is errors resulting from non-native speakers not knowing what to say or not saying the appropriate things as a result of transferring incongruent social rules, values and belief systems from their native languages and cultures. These types of errors are likely to cause a downright insult for both the nonnative and the native speakers of a certain language, or with native speakers misunderstanding and misinterpreting the intentions of the nonnative speakers, and the non-native speakers becoming over-sensitive to 'distinctions of grammatical form' (Brown and Levinson, 1987: 35), in a 
way the native speakers are not. In any case, being polite is essential to maintaining healthy social relations within a specific culture, and even more so, for the communication across cultures.

The work in intercultural and cross-cultural communication draws on general communication theory and is concerned with comparing cultural differences across such broad dimensions as individual/collective, personal/positional or even more generally as high versus low context cultures (Hofstede, 1994). In this tradition, attitude surveys are used to construct general statements about a national group. For example, Japan is said to have a high context culture (dependence on implicit assumptions and shared values) whereas America is said to be a low context culture (one in which roles and relationships are more explicitly negotiated) (Roberts et al. 2001: 32). Cross-cultural communication offers a wide field for research, as the sociopragmatic failure of one speaker of a certain community tends to be stereotyped for the whole community (Knapp and Hall, 2006: 203), consequently labeling a nation as rude, over-polite, insincere, etc. For instance, one is often confronted with statements like 'Russians are rude', 'The English are hypocrites', 'Japanese bow a lot', all of them resulting from a superficial comparison between the own pragmatic knowledge and the politeness strategies of the foreign culture.

Cultural differences have particular implications for intercultural communication, especially for interactions involving people whose backgrounds are one of the Asian cultures and for Australians (Irwin, 1996: 53). Chan (1992: 252) has offered a summary of differences in expression of communication style between traditional high-context, collectivist Asian cultures and low-context, individualistic cultures such 
as Australia as in the following table.

Table 1 Contrasting Communication Styles

\begin{tabular}{|l|l|}
\hline Characteristics of traditional Asian & $\begin{array}{l}\text { Characteristics of low-context, } \\
\text { individualistic cultures such as } \\
\text { Australia: }\end{array}$ \\
\hline $\begin{array}{l}\text { high-context, collectivist cultures: } \\
\text { Indirect, Implicit, nonverbal, } \\
\begin{array}{l}\text { Formal, Goal oriented, Emotionally } \\
\text { controlled, Self-effacing, modest }\end{array}\end{array}$ & $\begin{array}{l}\text { Direct, Explicit, verbal, Informal, } \\
\text { Spontaneous, Emotionally, } \\
\text { expressive, Self-promoting, } \\
\text { egocentric }\end{array}$ \\
\hline
\end{tabular}

Source: Chan (1992a:252)

\section{Tourism Service Improvement}

Tourism service providers in Central Java use various politeness levels based on local values in serving their tourists. From the most to the least polite are: (1) hotel employee, (2) tour guide, (3) travel agency officer, (4) restaurant employee, (5) tourist information center officer, (6) souvenir seller and (7) tourism object officer (Purnomo, 2011: 360). The policy makers of Central Java tourism industry have various reasons to respond the phenomena. They state why the hotel employee and travel agency officer are ranked as the top polite tourism service providers because of some factors: (1) the employee recruitment is very selective, especially for guest-contact employee; (2) they should obey standard operation procedure (SOP) made by the hotel/travel agency management to maintain their acceptable (polite) behavior and to improve their quality of service to guests. The factors are opposite to the tourism service providers who are ranked as the impolite ones.

The above phenomena reconfirm the need for energizing unggah ungguh as local values for tourism service improvement. The more 
unggah-ungguh the tourism service providers use, the more polite they are. In other words, improving the implementation of unggah-ungguh will affect to tourism service improvement.

\section{Research Method}

This study is of a qualitative and descriptive nature. It uses five techniques for collecting data: (1) observation and field notes; (2) recordings; (3) questionnaire; (4) in-depth interviewing; and (5) document analysis. The observation was done in an airport, tourist information centers, and travel agencies, hotels, and restaurants, places of interest, souvenir shops and excursions where the tourism service providers and the tourists made speech acts during their interaction. During the observation, the researcher took field notes. The field notes were written to complement the observation. In this research the recordings of informants were done to naturally. It means that they were not aware of being recorded. The recording was done by using a small tape recorder which has very high recording quality.

The purpose of using the questionnaire was to obtain information about unggah-ungguh 'politeness norms' as used by the tourism service providers based on the tourists' perception. From the 200 questionnaires distributed to tourists and then completed by them, the researcher selected them and found 120 which were considered representative. From these 120, 50 completed by English speaking tourists and 70 by the Indonesian speaking tourists. The 50 English speaking tourists came from Great Britain (10 persons), USA (20 persons) and Australia (20 persons). The 70 Indonesian speaking tourists came from various provinces, including Central Java Province. 
Interviews were undertaken by the researcher with tourism service providers to elicit the reasons why they used particular politeness norms during their interaction with the tourists. In this research the researcher analyzed documents of standard operation procedures (SOP) for tourism service providers to serve tourists produced by tourism industries in Central Java. The purpose in analyzing SOP documents is to know whether politeness norms are included in the standard of serving tourists.

\section{Discussion}

Data analysis for this research was undertaken in three steps: (1) sorting data corpus by giving data number, context and content of conversation; (2) analyzing data based on unggah-ungguh 'politeness norms'; and (3) analyzing data based on cross-cultural perspectives on unggah-ungguh. The total amount of the analyzed data was 127 data.

The following are the results of data analysis in this research.

a. Sumanak 'Friendly'

An examples of sumanak implemented by a tourism service provider when serving a tourist are as follows:

(1) Context: Conversation between a souvenir seller (S) and a tourist (T) in Kauman Batik Village

S: Ngersake nopo, Den? 'What do you want, Madam?'

T: Mau lihat-lihat batik. 'I want to see batik.'

S: Mangga .... mau yang halus atau yang biasa? 'Please ... you want the soft or the ordinary?'

T: Yang biasa aja, Bu. 'The ordinary, please.'

S: (S hands the batik samples to T). Mangga silakan pilih. Nanti pilihan warnanya banyak. 'Please choose by yourself. There are many color choices.'

T: Kalau yang ini berapa? 'How much for this?' 
S: Itu untuk bukaan dhasar ya... tujuh puluh lima ribu saja. 'For opening ... seventy five thousands rupiahs.'

In the first underlined expression, the souvenir seller begins her communication with a question in Javanese respectful or krama and uses address form Den (abbreviated from Raden) 'Madam' as a friendly typical of Javanese. Then in the second underlined expression, the seller pleases the tourist politely to see the batik and asking her wants, either the soft or ordinary batik. In the third underlined expression, the seller pleases tourist to choose the batik samples she handed to her. Therefore, it can be inferred that the seller's utterances Ngersake nopo, Den? 'What do you want, Madam?'; Mangga .... mau yang halus atau yang biasa? 'Please ... you want the soft or the ordinary?' and Mangga silakan pilih. Nanti pilihan warnanya banyak. 'Please choose by yourself. There are many color choices' follow sumanak (friendly).

Both foreign and Indonesian tourists considered that the S's utterance Ngersake nopo, Den? 'What do you want, Madam?' has a polite level. Either in the English speaking tourists' culture or in the Indonesian speaking tourists' culture, the use of indirect questions is considered to be more polite, especially to persons they have not familiar with. Moreover, both foreign and Indonesian tourists also stated that the S's utterances Mangga .... mau yang halus atau yang biasa? 'Please ... you want the soft or the ordinary?' and Mangga silakan pilih. Nanti pilihan warnanya banyak. 'Please choose by yourself. There are many color choices' have a polite level. Another similarity in the English speaking tourists' culture and in the Indonesia speaking tourists' culture, questions which let the tourists to have freedom of action are more liked 
by them.

Unlike the above example, the following example is a violation of sumanak implementation.

(2) Context: Conversation between a hotel receptionist (R) and a caller (C) through telephone

C: Halo. Masih ada kamar kosong, Mbak? 'Hallo. Do you have a room?'

R: Wah sudah penuh semua itu, Pak.. 'All rooms are occupied, sir.'

C: Masak satu pun nggak ada yang kosong? 'Really? I just want a room.'

R: Ya kebetulan semua kamar sudah dibooking tamu rombongan dari Jakarta. 'All rooms have been booked by a group from Jakarta.'

C: Hotel lain dekat-dekat situ masih punya kamar kosong nggak ya? 'Is there an available room in hotels near your hotel?'

$\mathrm{R}:$ Wah, ndak tahu ya. Bapak tanya aja sendiri. 'I don't know. Ask by yourself.'

In the underlined expressions, it seems that the reservation clerk does not nggatekake 'pay attention to what the caller's says, and ready to respond him'. Instead of sumeh 'showing a cheerful face while engaging in a conversation', she is mrengut 'frowning or showing a sour face'. Moreover, she does not want to help the caller to give information about an available room in other hotels. Therefore, it can be inferred that the reservation clerk's utterances Wah, ndak tahu ya. Bapak tanya aja sendiri 'I don't know. Ask by yourself' do not follow sumanak (friendly).

Both foreign and Indonesian tourists stated that the R's utterance Wah, ndak tahu ya. Bapak tanya aja sendiri 'I don't know. Ask by yourself' has an impolite level. In the both English and Indonesian 
speaking tourists' cultures, a hotel is well known as a hospitality industry. $\mathrm{C}$ who asks an available room means he intends to be its guest. $\mathrm{R}$ should also consider that he may be a repeating guest who must be maintained carefully. Although the hotel rooms are fully booked in this case, $\mathrm{R}$ should not act unconcerned when $\mathrm{C}$ asks an available room in nearby hotels. To make a polite expression, at least $\mathrm{R}$ can give some nearby hotel names along with their telephone numbers.

b. Sabar lan sareh 'Patient and with ease, calm'

An example of sabar lan sareh implementation by a tourism service provider when serving her tourist is as follows.

(3) Context: Conversation between a tour guide (G) and a tourist (T) in Laweyan Batik Village

T: Excuse me, I'm interested to know about the batik processing. Can you explain it to me, please?

G: Sure. Let's go to that room. ( $G$ and $T$ go to the processing room) This is the fabric that will be processed into batik material. First, it is colored by painting the desired patterns.

T: Yes, ....

G: Second, this special copper batik wax is dipped into melted wax, and stamped on the fabric.

T: I see ... it's hard work, isn't it? ... working near the stove.

G: Yes, that's because the application has to use melted wax. Besides, the worker has to take precaution to prevent the wax from dripping.

T: I never imagine the waxing process is quite complicated.

In the first underlined expressions, the tour guide respons the tourist patiently by inviting her to go to the batik processing room. Then he explains the first processing calmly. In the second underlined expressions, he explains the second processing in cekak aos 'brief but comprehensive', runtut 'ordered in a good sentence' and not in a nggladrah way 'utter long, irrelevant and unnecessary things'. In the last 
underlined expressions, the tour guide answers the tourist's question in cetha 'clear, distinct' way and not tumpang suh 'in disorder with lots of ovelapping'. Therefore, it can be inferred that the tour guide's utterances Sure. Let's go to that room and Yes, that's because the application has to use melted wax. Besides, the worker has to take precaution to prevent the wax from dripping follow sabar lan sareh (patient and with ease, calm).

Both foreign and Indonesian tourists stated that the G's utterance Let's go to that room 'Mari kita pergi ke ruangan itu' has normal level. Either in the English speaking tourists' culture or in the Indonesian speaking tourists' culture, the expression of invitation for a person who has a close relation with informal language is normal. Thus, the utterance Let's go to that room 'Mari kita pergi ke ruangan itu' is normal because the relation between the tourist and the tour guide has been closer. Still in the data (3), both foreign and Indonesian tourists also stated that the G's utterance Yes, that's because the application has to use melted wax. Besides, the worker has to take precaution to prevent the wax from dripping 'Ya, karena membatiknya harus menggunakan lilin yang dicairkan. Di samping itu, pembatiknya harus mencegah agar lilinnya tidak menetes' has a normal level. In the both English and Indonesian speaking tourists' culture, the expression of agreement followed by an explanation uttered by a tour guide is normal. This kind of explanation is in relevant with the definition of a tour guide, i.e. a person who guides tourists with a language chosen by them for a specific purpose about tourism objects and telling about their history of cultural heritage and local interest (www.worldtourism.com).

Unlike the above example, the following example is a violation of sabar lan sareh implementation. 
(4) Context: Conversation between a souvenir seller (S) and a tourist (T) in Triwindu Antique Market. $\mathrm{T}$ is bargaining for an antique plate

T: Harga pasnya berapa sih, Bu? 'How much is the fixed price, Madam?'

S: Tiga ratus lima puluh ribu, Pak. 'Three hundreds and fifty thousands, Sir.'

T: Bagaimana kalau dua ratus ribu? 'How about two hundred thousands?'

S: Kalau nggak mau ya sudah. Dari tadi kok nawar-nawar terus. Pembeli yang lain nanti juga masih banyak. 'No problem if you don't want to buy it. You're too much bargain from the beginning. There will be many buyers.'

In the underlined expressions, the souvenir seller uses utterances which are nyenyengit 'hateful' and rather galak 'vicious'. Instead of sabar 'patient' in serving the tourist during bargaining for the souvenir, she is gampang nesu 'get easily angry'. Therefore, it can be inferred that the seller's utterances Kalau nggak mau ya sudah. Dari tadi kok nawarnawar terus. Pembeli yang lain nanti juga masih banyak 'No problem if you don't want to buy it. You're too much bargain from the beginning. There will be many buyers' do not follow sabar lan sareh (patient and with ease, calm).

Both foreign and Indonesian tourists stated that the S's utterances Kalau nggak mau ya sudah. Dari tadi kok nawar-nawar terus. Pembeli yang lain nanti juga masih banyak. 'No problem if you don't want to buy it. You're too much bargain from the beginning. There will be many buyers' have an impolite level. In the both English and Indonesian speaking tourists' cultures, a seller is generally well known as a friendly person. S should also consider that $\mathrm{T}$ may be a repeating buyer who must 
be maintained carefully. Unfortunately, by those utterances, it seems that $\mathrm{T}$ is being chased away by $\mathrm{S}$.

c. Tepa slira 'Showing a feeling of sympathy or solidarity'

An example of the tepa selira implementation is as follows:

(5) Context: Conversation between a tour guide (G) and a tourist (T) in Kauman Batik Village. T is learning how to make batik

T: Lihat ini hasil batikanku. Bagaimana pendapatmu, Mas? 'Look at this, my creation of batik. What do you think, brother?'

G: Coba saya lihat ... Betul-betul indah. Tidak kalah dibanding pembatik profesional. 'Let me see ... It's really beautiful. Not inferior to a professional batik creator.'

In the underlined expressions, the tour guide gives appreciation and complementation to the tourist in the right situation. In other words, the tour guide ngajeni 'gives high respect, proper appreciation' to the tourist. Moreover, the tour guide acts to 'position himself at the place of addressee'. Therefore, it can be inferred that the tour guide's utterances Coba saya lihat ...Betul-betul indah. Tidak kalah dibanding pembatik profesional. 'Let me see ... It's really beautiful. Not inferior to a professional batik creator' follow tepa slira (showing feeling of sympathy or solidarity).

Both foreign and Indonesian tourists stated that the S's underlined utterances have a polite level. It seems that $G$ pays attention in the form of praise to $\mathrm{T}$. The praise is given because the tourists are able to make a batik painting.

Unlike the above example, the following example is a violation of tepa selira implementation.

(6) Context: Conversation between a tour guide $(\mathrm{G})$ and a tourist (T) at Triwindu Antique Market 
T: Lihat nih, Mas. Aku dapat cincin akik bagus. Hanya dengan seratus ribu rupiah. Tadi penjualnya minta lima ratus ribu. Sudah bagus, murah lagi. 'Look at this, brother. I've got a beautiful carnelian ring. Only with a hundred thousand rupiahs. The seller offered it five hundred thousands. It's beautiful and cheap.'

G: Kalau seratus ribu ya ndak murah. Saya dapat lebih bagus dari itu, bahkan hanya dengan harga lima puluh ribu. ' hundred thousands are not cheap. I can get the more beautiful on than it, even with only fifty thousands.'

In the underlined expressions, the tour guide does not show his sympathy to the tourist's happy feeling. Instead of expressing solidarity to what has been obtained by the tourist, he is even umuk 'conceited' and nggunggung diri 'brag or indulge in showing himself off' by claiming that he is able to get the carnelian ring which is cheaper and more beautiful than one obtained by the tourist. Therefore, it can be inferred that the tour guide's utterances Kalau seratus ribu ya ndak murah. Saya dapat lebih bagus dari itu, bahkan hanya dengan harga lima puluh ribu. 'A hundred thousands are not cheap. I can get the more beautiful on than it, even with only fifty thousands' do not follow tepa slira (showing feeling of sympathy or solidarity).

Both foreign and Indonesian tourists stated that the S's underlined utterances have an impolite level. It seems that $\mathrm{G}$ does not pay attention in the form of praise to $\mathrm{T}$.

d. Andhap asor 'Giving a high respect, appropriate appreciation'

An example of andhap asor implementation is as follows.

(7) Context: Conversation between a tour guide (G) and a tourist (T) at Mangkunegaran Palace

G: Bapak Ibu, kita sudah sampai pintu keluar Istana Mangkunegaran. Demikian yang bisa saya sampaikan. 
Mudah-mudahan Bapak Ibu berkenan. Bila ada kekurangan dalam memandu Bapak Ibu, saya mohon maaf yang sebesar-besarnya. 'Ladies and gentlemen, we have arrived at the exit gate of Mangkunegaran Palace. That was the information I can provide about this palace. Hopefully you are pleased with it. I apologize if I could not satisfy you during the guiding.'

T: Terima kasih, Mbak Ifah. Kami semua merasa puas dipandu oleh Mbak. Mbak Ifah sangat berpengetahuan luas mengenai istana ini. 'Thank you Miss Ifah. We are satisfied guided by you. You're very knowledgeable about this palace.'

G: Terima kasih kembali. Itu sudah menjadi tugas saya. 'You're welcome. It has become my duty.'

In the first underlined expression, the tour guide shows her 'low and humble' utterances by apologizing if she could not satisfy the tourists during her guiding service. In the second underlined expressions, she is still humble by saying that her satisfaction service felt by the tourist group is a kind of her duty. In other words, she does not act umuk 'conceited', ngunggung diri 'indulge in showing herself off' and degsura 'self-centered'. Therefore, it can be inferred that tour guide's utterances Bila ada kekurangan dalam memandu Bapak Ibu, saya mohon maaf yang sebesar-besarnya 'I apologize if I could not satisfy you during the guiding' and Terima kasih kembali. Itu sudah menjadi tugas saya 'You're welcome. It has become my duty' follow andhap asor (giving a high respect, appropriate appreciation).

Both foreign and Indonesian tourists stated that the G's underlined utterances have a polite level. In both cultures, utterances that indicate politeness markers to apologize and to gratitude are accepted.

An example of a violation of andhap asor implementation is as follows: 
(8) Context: Conversation between a tour guide $(\mathrm{G})$ and a tourist (T) at Kasunanan Palace

G: Kanjeng Sinuwun Pakubuwono XII disebut juga Sinuwun Hamardhika, karena tak lama setelah beliau naik tahta, Indonesia memproklamirkan kemerdekaan. 'The King Pakubuwono XII was also called The King of Independece, because not long after he reigned, Indonesia declared its independence.'

T: Wah saya belum lahir? 'Say, I was not born.'

G: Lha Ibu usianya berapa to? 'So, how old are you?'

T: Rahasia dong... 'It's secret...'

In the underlined expression, the tour guide asks the tourist's age which is not considered proper in relation to the speech event. Furthermore, asking private things like an age to the tourist is considered impolite. In other words, the tour guide is benyunyak-benyunyuk 'improper and unwelcome speech initiater'. Therefore, it can be inferred that the tour guide's utterance Lha Ibu usianya berapa to? 'So, how old are you?' do not follow andhap asor (giving a high respect, appropriate appreciation).

The English speaking tourists considered that the above utterance has an impolite level, but the Indonesian speaking tourists considered that it has a normal level. In the former culture, asking someone who has not been closed to about his/her age is impolite because it is privacy matter, but in the latter culture asking the similar question is normal.

e. Empan papan 'Matches with the setting and occasion'

An example of empan papan implementation is as follows:

(9) Context: Conversation between a tour guide (G) and a tourist (T) at the parking area of Mount Merapi National Park

G: Bagaimana Pak, bisa dilanjutkan perjalanan kita? 'So, can 
we continue our trip?'

T: Lha menara pandangnya mana? Apa masih jauh? 'Where is the observation tower?'

G: Itu tu kelihatan dari sini ... Cuma di sebelah bukit itu kok. 'That's seen from here ... It's only besides the hill.'

T: Bagaimana kalau jalan kaki saja ke sana? 'How about we walk there?'

G: Ya boleh. Berarti mobilnya kita parkir di sini saja. 'It's okay. So, we park the car here.'

In the underlined expressions, the tour guide's utterances suit the speech event and agree with the mood of the tourist. His agreement to go on foot and then the idea to park the car is nyambung 'connected with' the tourist's request. Therefore, it can be inferred that the tour guide's utterances Ya boleh. Berarti mobilnya kita parkir di sini saja 'It's okay. So, we park the car here' follow empan papan (matches with the setting and occasion).

Both foreign and Indonesian tourists considered that the G's underlined utterances have a normal level. To seek agreement in safe topics is common in both cultures.

An example of a violation of empan papan implementation is as follows:

(10) Context: Conversation between a tour guide (G) and a tourist (T) at Kauman Batik Village

T: Aduh ternyata berat juga ya bawa belanjaan segini banyak. 'Ouch! It's apparently heavy to carry as many as this merchandise.'

G: Tapi jalannya agak dipercepat, Bu. Kita buru-buru melanjutkan perjalanan ke tempat lain. 'But rather quick your walk, Madam. We're in hurry to continue our trip to another place.' 
In the underlined expressions, the tour guide's utterances do not agree with the setting and occasion. He does not care about the tourist's bustle carrying the items purchased. His request to the tourist to walk quickly does not suit the speech event and agree with the tourist's mood. In other words, the tour guide's utterances do not nyambung 'connect with' the finest sign of the woman's want who needs a help. Therefore, it can be inferred that the tour guide's utterances Tapi jalannya agak dipercepat, Bu. Kita buru-buru melanjutkan perjalanan ke tempat lain. 'But rather quick your walk, Madam. We're in hurry to continue our trip to another place' do not follow empan papan (matches with the setting and occasion).

The English speaking tourists stated that the above utterance has a normal level, but the Indonesian speaking tourists stated that it has impolite level. In the former culture, giving direct warning statement can be accepted, but in the latter culture giving such kind of statement is impolite, especially to person who is implicitly asking for help.

f. Nuju prana 'Pleasing, satisfying'

An example of nuju prana implementation is as follows:

(11) Context: Conversation between a male receptionist (R) and a female hotel guest $(\mathrm{G})$ in front of reception counter during check-out service. The guest has appropriated certain hotel belongings

G: Why should I pay for these items?

$\mathrm{R}$ : Yes, Madam. This bill is for two night stay, this is for food and this is for laundry.

G: But why you include two kinds of souvenir from this hotel? What do they mean?

R: All right, Madam. For guests who want to have souvenirs in guestroom, we charge them the same price as in souvenir shops. ( $R$ hands documents to $G$ ) So, please check this price list. For this item we charge five dollars and this one ten 


\section{dollars.}

G: Oh, umm ... okay. Do you mean you charge fifteen dollars for the towels in my bag?

R: You're right, Madam.

G: Why don't you put this price list in my room? I thought they're free of charge.

In the underlined expressions, it can be seen that by indicating to the guest that guests who want to have souvenirs from guestrooms can pay for them at the same price as in souvenir shops in fact the receptionist is hinting to the guest that she has taken hotel belongings. By that hint it is expected that the guest be tanggap ing sasmita 'responsive toward the finest sign'. As a Javanese, the receptionist still ngajeni 'treats her with respect' because in the hospitality industry the guest is the king. The problem solving expected by the receptionist, and also by the guest is ing buri tiba penake 'a happy outcome'. In other words, the receptionist has applied tepa slira 'showing a feeling of sympathy or solidarity'

Related to the use of above unggah-ungguh, English speaking tourists considered that the above utterance has an impolite level, but the Indonesian speaking tourists considered that it has a polite level. English speaking guest want the receptionist to answer directly why she should pay the hotel souvenir. On the other hand, with the high-context language, the receptionist answers indirectly and formally by stating the general rules of the hotel concerning the hotel's belongings. In the lowcontext culture, speaking indirectly and implicitly does not satisfy the hearer. Unlike the English speaking guest, the Indonesian speaking guest has the same culture as the receptionist, i.e. high-context, collectivist culture. Indonesian people, especially Javanese like to speak indirectly if they have a different opinion/conflict with a respected/high social status 
person. In the context of host-guest relationship, the guest has higher social status than the receptionist. Moreover the receptionist who has lower social status would like to try to speak formally and modestly as a sign of deference. In the tradition of collectivist culture, people would like to end the conflict in harmony.

An example of a violation of nuju prana implementation is as follows:

(12) Context: Conversation between a tour guide $(\mathrm{G})$ and a tourist (T) at Radya Pustaka Museum

T: Wah kerisnya bagus-bagus banget, ya? Koleksinya juga lengkap. 'Wow, the daggers are beautiful, aren't they? Their collection is also complete.'

G: Sudah-sudah. Waktu kunjungan hampir habis. Sebentar lagi museum akan ditutup. 'That's enough. The time to visit is almost up. For a few moments the museum will be closed.'

T: Lho gimana to, Pak? Kita kan belum lama lihat-lihatnya? 'How come, Sir? We're still not long to look around.'

In the underlined expressions, it shows that the tour guide's utterances are not ngresepake 'causing pleasant feeling'. The content of the speech is nglarani ati 'causing heart irritation' because he does not let the tourist has opportunity to see the collection of dagger he is interested in. Furthermore, the tour guide's expressions make the tourist's complaint. Therefore, it can be inferred that the tour guide's utterances Sudah-sudah. Waktu kunjungan hampir habis. Sebentar lagi museum akan ditutup 'That's enough. The time to visit is almost up. For a few moments the museum will be closed' do not follow nuju prana (pleasing, satisfying).

The English speaking tourists considered that the above utterances 
have a normal level, but the Indonesian speaking tourists considered that they have impolite level. In the former culture, stopping sightseeing activity to tourists because of the time of visit is up can be accepted, especially for people come from rules-obedient countries but in the latter culture giving such kind of statement is impolite. They like indirect statements better than direct ones.

\section{Conclusion}

This research has been able to answer the two research questions articulated in the Introduction.

First, the tourism service providers in Central Java use various unggah-ungguh 'politeness norms' to serve their tourists. The unggahungguh 'politeness norms' they use comprise (1) sumanak 'friendly', (2) sabar lan sareh 'patient and with ease, calm' (3) tepa slira 'showing a feeling of sympathy or solidarity', (4) andhap asor 'giving a high respect, appropriate appreciation', (5) empan papan 'matches with the setting and occasion' and (6) nuju prana 'pleasing, satisfying'. Besides that, there are some violations in using sumanak, sabar lan sareh, tepa slira, andhap asor, empan papan and nuju prana.

Secondly, there are similar and different perspectives on unggahungguh 'politeness norms' between English speaking Western tourists and Indonesian speaking tourists with Indonesian backgrounds towards the politeness norms used by the tourism service providers in Central Java. English speaking tourists tend to like tourism service providers to speak directly, explicitly, verbally, informally and spontaneously in their communication. On the other hand, Indonesian speaking tourists tend to like tourism service providers to speak indirectly, implicitly, formally, 
modestly and be emotionally controlled in their communication.

The findings imply the needs of energizing unggah-ungguh 'politeness norms' which is discovered from well known noble Javanese values used by the tourism service providers for tourism service improvement. To support the purpose, it is suggested that the local government of Central Java should campaign, disseminate and educate unggah-ungguh 'politeness norms' to their people, especially to tourism service providers as the ways to act, to behave and to talk during working in tourism industry.

Particularly in Central Java, the dissemination program will support the local government to brand the province with its cultural heritage, and spread it throughout the world. With this program, not only the tourismhuman resources, but mostly the Central Java people are supported to preserve their local values as an intangible cultural heritage. This notion will also encompass living expressions that has inherited from their ancestors and transmit to their descendants. Since 2001, intangible cultural heritage has received international recognition and its safeguarding had become one of the priorities of adoption of the Convention for the Safeguarding of the Intangible Cultural Heritage (UNESCO, 2011:1).

The findings can also be used in teaching language and ethics for tourism service providers in Indonesia, especially in Central Java, in serving international tourists who speak some English and local tourists who speak Indonesian. Moreover, the findings can be used as materials to develop models for improving quality of service to tourists using appropriate nuances of politeness in English, as well as in Indonesian for tourism service providers and students of tourism schools to improve 
their competence in cross-cultural communication.

\section{References}

Astika, Gusti (2004). Syllabus Design for Tour and Travel Management Department at Satya Wacana University Salatiga: A Policy Research to Develop an Alternative English Syllabus. Surakarta: Sebelas Maret University.

Brown, Penelope and Levinson, Stephen C. (1987). Politeness: Some Universal in Language Use. Great Britain: Cambridge University Press.

Chan, S. (1992). Families with Asian roots, eds. E. Lynnch \& M. Hanson, Developing Cross-Cultural Competence: A Guide for Working With Young Children and Their Families, Paul H. Brookes, Baltimore.

Departemen Pariwisata dan Budaya. Tourism Development in Indonesia. Retrieved 9 January 2010 from http://www.tourismindonesia.com.

Dinas Kebudayaan dan Pariwisata Pemerintah Kota Surakarta. Perkembangan Pariwisata Kota Solo. Retrieved 12 January 2010 from http://www.visit-solo.com.

Hofstede, G. (1994). Cultures and Organizations: Software of the Mind. London: HarperCollins.

House, J. and Kasper, G. (1981). Politeness markers in English and German in Coulmas F. (ed.) Conversational Routines. The Hague: Mouton.

Irwin, Harry (1996). Communicating with Asia: Understanding People and Customs. New South Wales: Allen \& Unwin.

Knapp, M. L. and Hall, J. A. (1992). Nonverbal Communication in Human Interaction. USA: Thomson Wadsworth.

Poedjosoedarmo, Soepomo (2009). Language Propriety in Javanese.

Journal Fenomena, Vol. VI No. 2, March - May 2009.

Yogyakarta: Lembaga Penelitian, Sanata Dharma University.

Purnomo, Budi (2009). Aspects of politeness when serving tourists in Indonesia, in Proceedings of the Symposium of Discourse Analysis. Melbourne: School of Languages, Cultures and Linguistics, Monash University. $5^{\text {th }}: 14$.

Purnomo, Budi (2011). Politeness in Tourism-Service Register in Central Java: A Sociopragmatic Study. Yogyakarta: Gadjah Mada University. 
Roberts, Celia et al. (2001). Language Learners as Ethnographers. London: Cromwell Press Ltd.

Samiati, M. Sri, Nurkamto, Joko, and Purnomo, Budi (2010). English for Tourism Based on Local Needs. Surakarta: Sebelas Maret University Press.

Thomas, J. (1995). Meaning in Interaction: An Introduction to Pragmatics. London: Longman.

UNESCO (2011). Convention for the Safeguarding of the Intangible Cultural Heritage. Retrieved 12 January 2012 from http://www.budpar.go.id. 
